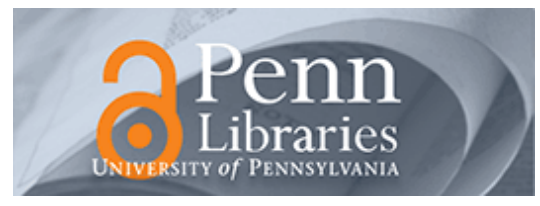

University of Pennsylvania

ScholarlyCommons

Accounting Papers

Wharton Faculty Research

\title{
8-2011
}

\section{Properties of Implied Cost of Capital Using Analysts' Forecasts}

Wayne R. Guay

University of Pennsylvania

S. P. Kothari

Susan Shu

Follow this and additional works at: https://repository.upenn.edu/accounting_papers

\section{Recommended Citation}

Guay, W. R., Kothari, S. P., \& Shu, S. (2011). Properties of Implied Cost of Capital Using Analysts' Forecasts. Australian Journal of Management, 36 (2), 125-149. http://dx.doi.org/10.1177/ 0312896211408624

This paper is posted at ScholarlyCommons. https://repository.upenn.edu/accounting_papers/89

For more information, please contact repository@pobox.upenn.edu. 


\title{
Properties of Implied Cost of Capital Using Analysts' Forecasts
}

\begin{abstract}
We evaluate the influence of measurement error in analysts' forecasts on the accuracy of implied cost of capital estimates from various implementations of the 'implied cost of capital' approach, and develop corrections for the measurement error. The implied cost of capital approach relies on analysts' short- and long-term earnings forecasts as proxies for the market's expectation of future earnings, and solves for the implied discount rate that equates the present value of the expected future payoffs to the current stock price. We document predictable error in the implied cost of capital estimates resulting from analysts' forecasts that are sluggish with respect to information in past stock returns. We propose two methods to mitigate the influence of sluggish forecasts on the implied cost of capital estimates. These methods substantially improve the ability of the implied cost of capital estimates to explain cross-sectional variation in future stock returns, which is consistent with the corrections being effective in mitigating the error in the estimates due to analysts' sluggishness.
\end{abstract}




\title{
Properties of IMPLIED COST OF CAPITAL USING ANALYSTS' ForeCASTS
}

\author{
Wayne Guay \\ The Wharton School \\ University of Pennsylvania \\ 2400 Steinberg-Dietrich Hall \\ Philadelphia, PA 19104-6365 \\ (215) 898-7775 \\ guay@wharton.upenn.edu \\ S.P. Kothari \\ Sloan School of Management, E52-325 \\ Massachusetts Institute of Technology \\ 50 Memorial Drive, \\ Cambridge, MA 02142 \\ (617) 253-0994 \\ kothari@mit.edu \\ Susan Shu \\ Boston College \\ 140 Commonwealth Avenue \\ Chestnut Hill, MA 02467 \\ (617) 253-1959 \\ shus@bc.edu
}

First draft: February 2003

Current version: September 2003

We thank John Core, Christian Leuz, Irem Tuna, Andrew VanBuskirk, Ross Watts, Jerry Zimmerman, and seminar participants at the University of Oregon and the University of Rochester for helpful comments. 


\title{
Properties of Implied Cost of Capital Using Analysts' Forecasts
}

\begin{abstract}
We evaluate cost of capital estimates from various implementations of the implied cost of capital' approach, as well as from the Fama and French three-factor model, on the basis of their ability to explain cross-sectional variation in future stock returns. The implied cost of capital approach relies on analysts' short- and long-term earnings forecasts as proxies for the market's expectation of future earnings, and solves for the implied discount rate that equates the present value of the expected future payoffs to the current stock price. We find the implied cost of capital estimates are uncorrelated with future annual and monthly returns, as are the Fama and French three-factor estimates. Further analysis shows predictable error in the implied cost of capital estimates resulting from analysts' forecasts that are sluggish with respect to information in past stock returns. We propose two methods to mitigate the influence of sluggish forecasts on the implied cost of capital estimates and provide evidence that these approaches improve the ability of the implied cost of capital estimates to explain future returns.
\end{abstract}




\section{Introduction}

Accurate estimates of the cost of capital are crucial to evaluating investment alternatives and for valuation, but academics and practitioners find it challenging to precisely estimate firms' cost of capital. The state of the art method for estimating the cost of capital in the financial economics literature employs the Fama-French three-factor model (see Fama and French, 1993). However, Fama and French (1997) demonstrate the difficulties encountered in accurately estimating the cost of capital even with the three-factor model. The three-factor cost-of-capital estimates are imprecise at the firm as well as the industry level.

To obtain alternative, potentially superior measures of the cost of capital, a string of papers, including Gebhardt, Lee and Swaminathan (2001), Claus and Thomas (2001), and Botosan and Plumlee (2002), have turned to an 'implied-cost-of-capital' approach. ${ }^{1}$ These studies begin by assuming a valuation model, such as the Feltham-Ohlson residual income model. They then use analysts' short- and long-term earnings forecasts as proxies for the market's expectation of future earnings. Finally, they solve for the implied discount rate that equates the present value of the expected future payoffs (residual earnings or dividends) to the current stock price.

Research on implied cost of capital estimates is motivated on the grounds that (i) the extant finance approaches to estimating the cost of capital are deficient, and (ii) implied cost of capital estimates can be superior to other approaches (e.g., because the implied methods do not require an historical time series of data and are not based on realized stock returns). For example, Gebhardt et al. (2001, p. 171) take the view that the current methods of "cost-of-capital estimation advocated in standard finance textbooks have yielded few useful guidelines for finance professionals." Gebhardt et al. (2001, p.171) conclude that, "Despite the caveats and limitations discussed above, we believe the approach outlined here holds much more promise,"

\footnotetext{
${ }^{1}$ Also see Botosan (1997), Easton (2001), and Easton, Taylor, Shroff, and Sougiannis (2002).
} 
and go on to suggest ways in which the implied cost of capital estimates can be used in capital budgeting and investment decisions.

While many different implied cost of capital estimates appear in the literature, no one to date has conducted a systematic study of the properties of these estimates. All of the implied cost of capital estimates rely on the same underlying theory, i.e., discounted cash flow valuation. However, because individual applications differ in their implementation, each produces a cost of capital estimate with somewhat different properties. Absent a comparative evaluation, it is impossible to choose among the alternative implied estimates. Nor is it possible to infer that implied cost of capital estimates are superior to the standard finance approach to estimating the cost of capital (e.g., the Fama-French three-factor model).

A priori, some salient features of implied cost of capital estimation suggest there are pros and cons to this approach. For example, the implied cost of capital approach relies on analyst forecasts of near- and long-term earnings as proxies for the markets' earnings forecasts that are reflected in stock prices. On one hand, making use of analysts' forward-looking information might help increase the precision of the cost of capital estimates and thus improve upon the Fama-French three-factor approach. On the other hand, analyst forecasts are subject to timeliness and bias problems that might adversely affect the accuracy of the implied cost of capital approach. For example, Lys and Sohn (1990) find that analyst's near-term earnings forecasts contain only $66 \%$ of the information reflected by security prices prior to the forecastrelease date. Our evidence suggests that the sluggishness is even more characteristic of analysts' long-term earnings forecasts, which receive a large weight in the estimation of the implied cost of capital. If analysts fail to quickly revise their forecasts with stock price changes, analysts' earnings forecasts will be a poor proxy for the market's expectation of earnings. Using sluggish forecasts in the valuation models introduces error in the cost of capital estimates, with the error being correlated with past security price performance. 
To see the relation between the error in the cost of capital estimate and recent return performance, consider a large stock price run-up prior to estimating the cost of capital, where the change in stock price reflects market revisions in estimated future earnings. If analysts do not fully incorporate the new information contained in the stock price, the valuation model forces an artificially low cost-of-capital estimate to maintain the pricing equation, i.e., the price equal to the discounted present value of expected residual earnings plus the book value. Conversely, following a steep price decline, unless analysts fully revise their forecasts, the estimates of implied cost of capital will be too high. ${ }^{2}$

Because the implied cost of capital estimates all suffer from the aforementioned estimation problems to varying degrees, ultimately their properties can be ascertained only empirically. Specifically, which among the class of implied cost of capital estimates is the best, and whether the best measure outperforms the Fama-French three-factor estimate is an empirical question. Our paper's objective is to evaluate the various cost of capital estimates, especially the class of 'implied costs of capital.' Our assessment is based on the standard test in the finance literature: Do the cost of capital estimates explain cross-sectional variation in subsequent realized returns, which would be consistent with a positive risk-return trade-off? ${ }^{3}$

We generate the implied cost of capital estimates using four applications of the FelthamOhlson residual income and the dividend discounting valuation models. The applications differ mainly in their assumptions about terminal earnings growth and the decay in the analysts'

\footnotetext{
${ }^{2}$ A decline in the cost of capital simultaneously with a sharp rise in stock price or an increase in the cost of capital simultaneously with a fall in the stock price is also predicted on economic grounds in an efficient market. As a firm's cost of capital changes through time, holding expectations of cash flows constant, prices move in the opposite direction to reflect the change in the present value of expected cash flows due to the discount rate effect. See French, Schwert, and Stambaugh (1987), Fama and French (1988) and Ball and Kothari (1989) for the arguments and evidence. We discriminate between economic reasons for changes in the cost of capital and predictable changes in the implied costs of capital that arise due to sluggish revisions of analyst forecasts following large price changes by examining the relation between the cost of capital estimates and future stock returns. In the former case, this relation should be significantly positive, whereas in the latter case, this relation will be biased toward zero.

${ }^{3}$ See Fama and MacBeth (1973) and Fama and French (1992), and a vast body of literature employing FamaMacBeth cross-sectional regressions to test the joint hypothesis of market efficiency and a model of expected returns, e.g., the CAPM.
} 
forecast of long-term earnings growth before it stabilizes at the terminal earnings growth rate. The four different models we study are: Gebhardt et al. (2001), Claus and Thomas (2001), Ohlson and Juettner-Nauroth (2000), and the finite Gordon growth model.

Summary of results. For a large cross-section of stocks, we estimate the implied cost of capital annually using each of the four models. We then cross-sectionally regress future returns on the various cost-of-capital measures, i.e., estimate Fama-MacBeth regressions of returns on estimated costs of capital, where all the inputs into the cost of capital estimation are available prior to the return measurement period. The cross-sectional regressions are estimated from 1982 to 2000 using monthly and annual returns on individual stocks and industry portfolios. The joint hypothesis of market efficiency and accurate estimation of the implied cost of capital predicts a slope coefficient of one in the estimated regressions. We fail to observe a significant slope coefficient for any of the four implied cost of capital models using one-year ahead or one-month ahead returns, and only the estimates based on Gebhardt et al. (2001) exhibit a significant positive relation with two-year- and three-year-ahead returns. Consistent with previous literature, the Fama-French three-factor model estimates appear to be noisy, and their cross-sectional association with future returns is statistically indistinguishable from zero.

The lack of a significant positive average coefficient in the Fama-MacBeth regressions using various cost of capital estimates is attributable to at least two reasons. First, even in an efficient market, the average slope coefficient from the Fama-MacBeth regressions over a 19year period can be indistinguishable from zero due to insufficient power (see Fama and French, 1992, and Kothari, Shanken, and Sloan, 1995). Second, it might be that the cost of capital estimates are too noisy and/or biased such that the estimated relation between returns and the cost of capital estimates is flat. There is not much we can do to address the first concern because of the lack of availability of analysts' forecasts prior to the 1980s, which makes it almost impossible to implement the implied cost of capital models. Therefore, we explore the second reason, i.e., noise and/or systematic errors in the implied cost of capital estimates. 
We document that implied cost of capital estimates using analysts' earnings forecasts contain a predictable error attributable to analysts' sluggish revisions of their forecasts. We show that this error is negatively correlated with the firm's immediate past price performance, and that the negative relation varies with the firm characteristics such as size, book-to-market ratio, and analyst following. We also document that the magnitude of the error appears to be substantial. During our 1982-2000 sample period, approximately $15 \%$ of the firms' implied cost of capital estimates are below the ten-year Treasury-bond yield (economic theory suggests the equity cost of capital should exceed Treasury-bond yields). In some years, the cost of capital estimates for as many as $40 \%$ of the firms are below the Treasury-bond yield. Consistent with measurement error in these estimates, we find that a majority of these firms experienced large positive returns prior to the time of estimating the implied cost of capital.

Because the Fama and French cost-of-capital estimate does not rely on analyst forecasts, it does not suffer from the same type of predictable estimation error and does not exhibit the same negative relation with past returns. The Fama-French estimates do, however, contain considerable estimation error, as indicated by the fact that $15 \%$ of the cost of capital estimates are below the Treasury-bond yield.

Finally, we show that recent stock price performance can econometrically "correct" the sluggishness in analysts' earnings forecasts, which improves the ability of the implied cost of capital estimates to explain future returns in the Fama-MacBeth cross-sectional regressions. With past return included to proxy for the sluggish component in analyst forecasts, the cost of capital estimates from the Gebhardt et al. (2001) and finite Gordon models are significantly positively related to one-year ahead stock returns. We also propose an alternative estimation procedure for the accounting-based cost of capital models that reduces the influence of sluggishness in analysts' forecasts. Using this procedure, the implied cost of capital estimates from the Gebhardt et al. (2001) and finite Gordon models are relatively more strongly correlated 
with future returns. We caution, however, that our approaches to address sluggishness of analysts' forecasts are neither perfect nor successful in every individual firm.

Contributions to the literature. Our study contributes to the literature in several ways. First, we provide the intuition for and present a systematic analysis of the limitations of implied cost-of-capital estimates. While a potential advantage of an implied cost of capital estimate is that it uses forward-looking information in analyst forecasts, we study the central importance of the timeliness of the forecasts in generating accurate cost of capital estimates. We suggest means of correcting for the sluggishness of analysts' forecasts.

Second, since we find that the error in the implied cost of capital estimates is negatively correlated with past performance, inferences about the market risk premium (defined as the expected return on the market portfolio minus the risk-free rate of return) on the basis of estimated implied costs of capital might be incorrect. Specifically, since previous research on implied cost of capital (see Claus and Thomas, 2001, and Gebhardt et al., 2001) estimates the market risk premium following the bull market of the 1990s, it might have produced too low an estimate of the risk premium (about 2-3\% per annum).

Finally, we extend the previous literature (e.g., Lys and Sohn, 1990, and Dechow and Sloan, 1997) on the errors in analyst forecasts. Much of the past research focuses on analysts' short-term forecasts, whereas we offer evidence on the biases in both short- and long-term forecasts as a function of a security's past performance. LaPorta (1996), Dechow and Sloan (1997), and others contend that the market might be fixated on analyst forecasts that are overly optimistic or pessimistic, i.e., analyst overreaction. The market's fixation on the forecasts leads to market overreaction, followed by return reversals. Our evidence suggests another (nonmutually exclusive) dimension to analysts' long-term forecasts, i.e., analysts underreact to information in prices, which leads to predictable analyst forecast errors. We do not study future security price behavior to draw inferences about the market's fixation on the forecasts. 
Section 2 reviews related literature. Section 3 describes how we obtain our data and provides descriptive statistics. In Section 4, we present empirical results. Section 5 concludes.

\section{Related literature and motivation for our study}

Starting with Botosan (1997), many studies estimate the implied cost of capital using the stock price of a security, analysts' short- and long-term earnings forecasts, and some variation of the residual income or the dividend discounting valuation model (see references in the Introduction). Accumulated evidence on the properties of the cost of capital estimates in the finance literature provides the impetus for estimating the cost of capital using forward-looking earnings information rather than historical stock returns. An unmistakable conclusion from the literature is that the cost of capital estimates based on the CAPM or related asset-pricing models (e.g., the Fama-French three-factor model) are imprecise (e.g., Fama and French, 1997). The asset-pricing-based estimates of the cost of capital are typically obtained using the combination of a security's and the market's historical time series of monthly or daily returns over a fairly long period (one-to-five years). In contrast, the implied cost of capital estimates use forwardlooking information in analysts' forecasts.

The growth in the implied cost of capital research suggests that the distinction between the historical returns-based estimation and the forward-looking information-based estimation potentially imparts superiority to the implied cost of capital estimates over the asset-pricingbased estimates. However, direct evidence evaluating the asset-pricing-based estimates against the implied cost of capital estimates is lacking in the literature. Several strengths of the implied cost of capital models have been articulated in the literature. First, the estimates are correlated with risk proxies like return volatility, firm size, analyst following, book-to-market ratio, growth, and sometimes beta. ${ }^{4}$ However, the correlation evidence tends to be mixed. For example,

\footnotetext{
${ }^{4}$ Since the primary motivation for estimating the implied cost of capital is that the CAPM beta is not successful in precisely estimating the cost of capital, evidence that the implied cost of capital estimates are correlated with beta is not particularly helpful (see Gode and Mohanram, 2003, who recognize this point).
} 
Botosan (1997, table 4) reports a significant positive correlation between implied cost of capital and beta, whereas Gebhardt et al.'s (2001, table 4, panel A) quintile analysis indicates a negative association between the quintile portfolios' implied costs of capital and beta estimates. Gode and Mohanram (2003, table 3) find that the Ohlson and Juettner-Nauroth implied cost of capital is significantly positively associated with analysts' short- and long-term growth forecasts, but Gebhardt et al.'s estimates (2001, table 4, panel E) are significantly negatively correlated.

Second, some studies report average future returns to portfolios of stocks ranked on the basis of their estimated implied cost of capital (e.g., Gebhardt et al., 2001, and Gode and Mohanram, 2003). If the portfolios' average future returns are positively correlated with the estimated cost of capital, the evidence is interpreted as supportive of the implied cost of capital estimation. While such an approach is certainly a step in the right direction, the standard methodology in the financial economics literature is to draw inferences from the time-series average of the estimated coefficients from Fama-MacBeth cross-sectional regressions of returns on betas or the estimated cost of capital (see Fama and MacBeth, 1973, Campbell, Lo, and MacKinlay, 1997, pp. 215-217). Testing whether the time-series average coefficient is significantly positive is motivated by economic considerations. The joint test of market efficiency and the model employed to estimate the cost of capital predicts that the average of the estimated slope coefficients from Fama-MacBeth cross-sectional regressions is significantly positive. $^{5}$ That is, the time-series variability that the cross-sectionally estimated coefficients exhibit is economically relevant in assessing the significance of the average coefficient (see Shanken, 1985, p. 337) under the joint hypothesis of efficiency and model validity. A test that examines whether (time-series) average portfolio returns are increasing in the estimated cost of capital cannot inform us about the validity of the economic hypothesis of a positive risk-return

\footnotetext{
${ }^{5}$ If returns are cross-sectionally regressed on the estimated cost of capital, then the average coefficient is predicted to be one, whereas if they are regressed on betas (as in Fama and MacBeth and many other studies) then the average coefficient is an estimate of the market risk premium.
} 
trade-off that underlies the test being conducted. If time-series average portfolio returns are used, the time-series variability is eliminated and the significance of the slope coefficient from a regression of average portfolio returns on the average implied cost of capital is overstated.

Another disadvantage of estimating a pooled cross-sectional regression of returns on cost of capital estimates is that it suffers from econometric problems like cross-sectional dependence that might bias the significance levels. Additionally, the estimated coefficient in a pooled crosssectional regression can be unduly influenced by observations from a year (or years) in which the market exhibited extreme performance, which is a form of the heteroskedasticity problem. ${ }^{6}$

In light of the preceding discussion, we conduct the following analyses. First, we compare the ability of the various implied cost of capital estimates and the Fama-French threefactor model cost of capital estimate to explain cross-sectional variation in realized future returns using Fama-MacBeth regressions. Second, we examine whether the implied cost of capital estimates exhibit systematic biases that are correlated with securities' past price performance and whether the biases are related to the analysts' sluggish revisions of short- and long-term forecasts. Finally, we propose some remedies to correct for the biases in the estimated implied costs of capital.

\section{Models, Sample Selection and Data}

In this section, we describe the five models for estimating the cost of capital, and highlight some of the predictable differences across the estimates based on the underlying assumptions of the models. We then explain the criteria we use to obtain the sample for our empirical analysis. Finally, we present descriptive statistics of the cost of capital estimates using the five models.

\footnotetext{
${ }^{6}$ The weight assigned to observations from the year in which the market exhibits extreme performance is typically far greater in a pooled cross-sectional regression than in the Fama-MacBeth regressions in which the coefficient from each year is weighted equally.
} 
Cost of capital estimates. We study five models of estimating the cost of capital: Gebhardt et al. (GLS), Claus and Thomas (CT), Ohlson and Juettner-Nauroth (OJN), the finite Gordon model (Gordon), and the Fama and French three-factor model (FF). We follow the procedures in Gode and Mohanram (2003) in computing the OJN estimate. Table 1 summarizes the salient features and key assumptions underlying the five models. The first four are variations of the implied-cost-of-capital estimation approach, where stock prices and analyst earnings forecasts are substituted into the valuation equation to solve for the cost of capital.

The four implied cost of capital approaches share the same underlying valuation model, i.e., the discounted cash flow model, but each approach casts the valuation model slightly differently. The Gordon model uses the discounted dividend model, whereas the other three rely on the residual income model. Of these three, GLS specifies the pricing equation using 'return on equity' rather than the level of residual earnings as in CT and OJN. The discussion below highlights how these and other differences might affect the properties of the cost of capital estimates from the four models.

To simplify the notations, we set year $t$ to year 0 . To compute the cost of capital at the end of year 0 , each implied cost of capital model requires short-term earnings forecasts, i.e., years 1 and 2. In addition, long-term earnings forecasts are needed, where the long-term is from years 3 to $\mathrm{T}$, and $\mathrm{T}$ is the terminal year beyond which a steady-state earnings behavior is assumed in each model. The researcher employing a model specifies period $\mathrm{T}$ based on economic assumptions, e.g., the number of years it might take for competition to eliminate above-normal accounting rates of return for a firm or an industry. Finally, each model (or researcher) specifies a steady-state earnings growth rate beyond year $\mathrm{T}$. 
The models differ mainly with respect to their assumptions about the long-term forecast horizon and steady-state earnings growth rate. First, the four models assume different lengths of $\mathrm{T}$ and the forecasted earnings growth between 3 and $\mathrm{T}$. The finite Gordon model and CT essentially use the 5 -year growth rate from $\mathrm{I} / \mathrm{B} / \mathrm{E} / \mathrm{S}$ as the long-term earnings growth rate. GLS has a more elaborate approach and allows the ROE to fade linearly to the industry ROE by $\mathrm{T}$. GLS is the only approach that incorporates industry information. If industry performance is an important determinant of the cost of capital, GLS estimate of the cost of capital would be superior to the other measures. OJN's implementation of the implied cost of capital model does not require an explicit specification of the length of $\mathrm{T}$.

Second, the models differ in their assumptions of the growth rate beyond T. In CT and OJN, the growth rate after reaching the terminal period equals the inflation rate. In GLS, each firm earns the industry median ROE beyond year $\mathrm{T}$ under the assumption that such a growth rate is "value neutral." However, if an industry has performed well historically, the industry median ROE might be above normal, and therefore an industry median ROE in perpetuity beyond year $\mathrm{T}$ might not be value neutral. Ceteris paribus, the lower the growth rate assumed beyond year $\mathrm{T}$ in GLS, the lower the estimated cost of capital because current price equals the discounted sum of future residual income in the pricing equation.

Sample selection. We obtain analyst forecast and stock price data from IBES, financial accounting data from Compustat, and stock return data from CRSP. We use analyst forecasts from I/B/E/S from 1982 to 2000. Although I/B/E/S data date back to 1979, we start our sample period from 1982 because long-term earnings growth rates are not available prior to 1982 . We follow Claus and Thomas and Gebhardt et al., and estimate the cost of capital for each model as of July 1 each year. Consistent with these previous studies, we collect analyst forecast data from 
June of each year for all firms, rather than from different points in the year depending on the fiscal year-end of each firm. To ensure that we have all the necessary data to compute all five cost of capital estimates, we require a firm to have one-year ahead earnings forecasts, two-year ahead earnings forecasts, and a five-year earnings growth forecast. The one-year (two-year) ahead forecast corresponds to earnings for the first (second) fiscal year ending after the month in which the forecast is made. We obtain the June-end stock price from IBES to ensure comparability with IBES forecasts. ${ }^{7}$ The prices on IBES are usually for the day before IBES releases their monthly earnings forecasts. We obtain financial data on book value of equity, dividends and prior earnings from Compustat. We measure these variables for the most recent fiscal year ending prior to June. All per share data from Compustat is split adjusted to be compatible with the I/B/E/S numbers. These procedures ensure that as of the end of June, the cost of capital estimate is an ex ante measure that relies only on information known prior to this date. ${ }^{8}$ We use CRSP data to obtain monthly and annual stock returns for the three years starting in July (the month immediately following the June cost of capital estimation date).

For a firm-year to be included in our sample, we require non-missing data on consensus analyst forecast and stock price from June, financial data for the most recent fiscal year ending prior to June, and stock returns for at least one year starting in July. To operationalize the OJN

\footnotetext{
${ }^{7}$ IBES back adjusts their forecasts and price data to reflect splits over time. This means historical data appear on the same basis as current data. In contrast, CRSP and Compustat, do not back-adjust the data. The CRSP and the IBES prices differ by the cumulative adjustment factor that is available on CRSP and Compustat. The adjustment factor reflects the impact of stock splits on share prices and EPS.

${ }^{8}$ For example, for December fiscal-year end firms, book value of equity is taken from December, stock price from the end of the following June, and consensus analysts' forecasts from June. For April fiscal-year end firms, we use the same June dates to measure stock price and analysts' forecasts, but measure book value of equity as of April. A potential measurement problem for firms with fiscal years ending between January and June is that the fiscal yearend book value of equity may not be known to investors as of June. For firms with fiscal years ending between July and November, book value of equity is known by investors as of the following June, but may be a stale measure of book value. We check the severity of this measurement issue by examining the sensitivity of our results to using only December fiscal year firms and confirm that our results are robust to using this subsample of firms.
} 
model, we follow Gode and Mohanram and require one-year ahead and two-year ahead earnings forecasts to be positive. The resulting sample sizes annually from 1982 to 2000 are reported in Table 2. The number of observations increases over time, from 1,045 in 1982 to 2,585 in 2000. These numbers exceed those reported in Gebhardt et al. because they restrict their sample to NYSE/AMEX stocks. Our sample is also greater than Gode and Mohanram because they restrict their sample to firms (i) with market capitalization exceeding \$100 million and (ii) with at least five analysts making earnings forecasts. ${ }^{9}$

Using these data, we calculate the implied cost of capital, $r$, for each of the models. Of the four implied cost of capital models, only the OJN model has a closed form solution to the pricing equation that can be solved for the cost of capital, $r$, as shown in Gode and Mohanram (2003). For the remaining three models, we solve for $r$ by searching over the range of 0 to $100 \%$ for a value of $r$ that minimizes the difference between the discounted present value of residual income (using $\mathrm{r}$ as the discount rate) and current price, $\mathrm{P}_{0}$. Although not tabulated, the cost of capital estimation procedures generate some extreme values. An average of $25 \%$ of the finite Gordon estimates each year are below the risk-free rate (ten-year Treasury rate), followed by 19\% for the GLS estimates, 15\% for the Fama and French estimates, 6\% for the CT estimates, and finally $2 \%$ for the OJN estimates. There are also cases where the cost of capital estimates are in excess of $50 \%$, but these cases are rare and average between 0 and $0.8 \%$ each year. In the remainder of our analysis, we winsorize the cost of capital estimates at the ten-year Treasury rate and at $50 \%$.

The fifth cost of capital model we investigate is the Fama and French three-factor model, where the size factor is defined as small minus large firm returns (SML), the book-to-market

\footnotetext{
${ }^{9}$ Our results are robust to using the Gode and Mohanram (2003) sample selection criteria.
} 
factor is defined as high minus low book-to-market firm returns (HML), and the market factor is defined as the excess return on the CRSP value weight portfolio $\left(\mathrm{R}_{\mathrm{m}}-\mathrm{R}_{\mathrm{f}}\right)$. We obtain monthly time-series returns on the three factors, SML, HML, $\mathrm{R}_{\mathrm{m}}-\mathrm{R}_{\mathrm{f}}$, from Kenneth French's website. The loadings on the factors, $\mathrm{b}, \mathrm{s}$, and $\mathrm{h}$, are slope coefficients estimated from the following regression model for firm i:

$$
R_{i}-R_{f}=a_{i}+b_{i}\left[R_{m}-R_{f}\right]+s_{i} S M L+h_{i} H M L+e_{i} .
$$

We re-estimate the three-factor model each year for each firm using a rolling window of five years of monthly returns ending in the month of June. Firm i's estimated loadings multiplied by the average returns for the three factors from 1963-2000 gives the cost of capital for firm i (see Fama and French, 1997). We then annualize the number, which is our cost-ofcapital measure at June.

Descriptive statistics. Table 2, Panel A displays descriptive statistics for the cost of capital estimates using the five models. We report year-by-year average values as well as the mean and median of the annual averages across the years 1982 to 2000. For comparison, we also report the average one-year future realized return, $R_{1}$, measured from July 1 to June 30 . Consistent with the findings in recent research that accounting-based cost of capital estimates are lower than estimates based on ex post returns (see Claus and Thomas, 2001, and Gebhardt et al., 2001), the Fama-French three-factor cost of capital estimates are consistently higher than the accounting-based estimates. The Fama-French cost of capital averages $16.0 \%$ over the sample period compared to between $10.1 \%$ and $14.3 \%$ for the accounting-based estimates. The temporal variation in the estimated cost of capital is greatest for the CT estimates (standard deviation of annual means $=2.8 \%$ ) and least for the OJN estimates (standard deviation of annual means $=$ 
$1.2 \%$ ). The average annual return over the sample period, $17.4 \%$, is substantially greater than the accounting-based cost of capital estimates.

Panel B of Table 2 provides pair-wise correlations between the cost of capital estimates. We compute annual cross-correlations among the measures from 1982 to 2000 and report the time-series average correlations. The four accounting-based cost of capital measures are quite highly correlated with each other, with the average annual cross-correlations ranging from 0.50 to 0.87 . The significant positive cross-correlations are not surprising, however. The models rely on many of the same inputs (e.g., stock price and analysts' earnings forecasts) and are similar in their computational technique of setting the price equal to the discounted value of expected future residual earnings. In contrast, the Fama-French cost of capital estimates are based on a different computational technique and are not highly correlated with the accounting-based estimates. The average annual cross-correlation between the Fama-French estimates and the implied cost of capital estimates ranges from 0.13 to 0.15 .

\section{Results}

In this section we first investigate the relation between future realized returns and the cost of capital estimates (section 4.1). We then explore one potential explanation for the insignificant relation between the two, i.e., sluggish analyst forecasts (section 4.2). We propose a specification to econometrically mitigate the potential biases in the regression coefficients of realized returns on cost of capital estimates (section 4.3). We also propose an alternative estimation procedure for the accounting-based cost of capital models that adjusts for sluggishness in analysts' forecasts. 


\subsection{THE RELATION BETWEEN COST OF CAPITAL ESTIMATES AND REALIZED RETURNS}

As noted in Section 1, we evaluate the different cost of capital estimates using their correlation with future realized returns as a metric. If the accounting-based valuation models generate cost of capital estimates that improve upon the more traditional finance methods, these estimates should exhibit a stronger positive correlation with future stock returns. For each of the four accounting-based models and the Fama-French approach, we estimate Fama-MacBeth regressions of future firm stock returns on the cost of capital estimates. We run cross-sectional regressions annually at both the firm level and the industry level. For our industry groupings, we use the Fama and French classification of 48 industries. We average the annual regression coefficients on the cost of capital estimates across the nineteen sample years from 1982-2000. We use the standard deviation of the time series of coefficients over the 19 sample years to compute a t-statistic to test the hypothesis that the average coefficient is equal to zero. We also repeat the entire analysis using monthly instead of annual returns.

Table 3 reports the mean and median coefficients across the nineteen sample years, the time-series standard deviation of the estimated coefficients, the t-statistic testing whether the mean coefficient is different from zero, and the mean adjusted r-squared from the annual regressions. As can be seen from the table, the mean coefficients on the cost of capital estimates are neither consistently positive, nor significantly different from zero for both the firm level and industry level regressions. This result holds for both the accounting-based cost of capital estimates and the Fama-French estimates. In untabulated tests, we also estimate the FamaMacBeth regressions on a monthly basis. We find results that are similar to those in Table 3 , regardless of whether the regressions are run at the firm level or the industry level. 
Overall, our tests provide no evidence that accounting-based cost of capital estimates are positively correlated with one-year-ahead stock returns. We also fail to find evidence that the Fama-French cost of capital estimates are correlated with future returns.

There are at least three possible reasons why we find no significant relation between the implied cost of capital estimates and realized returns using the Fama-MacBeth approach. First, as we note in section 2 , our tests might lack power because we have only nineteen years of data. Second, the cost-of-capital measures are undoubtedly estimated with considerable error because several assumptions about the parameters of the valuation equation, e.g., the growth rate and the terminal value, underlie their estimation. These measurement errors bias the coefficients on the cost of capital estimates towards zero in the Fama-MacBeth regressions. Finally, there could be potential biases induced by sluggish analyst forecasts where prices impound new information about future earnings more quickly than do analysts' forecasts. ${ }^{10}$ This is a variant of the estimation error argument noted above (i.e., the second reason) in that it induces a predictable error as opposed to a random error in the estimated cost of capital. In the next section, we explore the third conjecture about sluggish forecasts. We are not able to directly address the first two concerns.

\subsection{EVIDENCE ON BIAS IN ACCOUNTING-BASED COST OF CAPITAL ESTIMATES}

As described in Section 1, an accounting-based valuation model provides an accurate estimate of a firm's cost of capital only if timely and informed estimates of future earnings are used as inputs to the model. In this section, we provide evidence that analysts' forecasts of

\footnotetext{
${ }^{10}$ Another source of error (or bias) in the estimated cost of capital can be optimistic analyst forecasts (see Stickel, 1990, Abarbanell, 1991, Brown, et al., 1985, Brown, 1997, Lim, 2001, and Gu and Wu, 2003 for discussions of analyst forecast bias). If analyst forecasts are optimistic, then the valuation model forces an artificially high implied cost of capital to maintain the pricing equation. In Section 4.3, we describe robustness tests that investigate the relation between cost of capital estimates and future returns after controlling for known determinants of optimism in analysts forecasts.
} 
future earnings are not updated in a timely fashion, and as a result, empirical applications of accounting-based valuation models produce biased cost of capital estimates. Specifically, we document that when stock prices adjust to information more quickly than analysts' forecasts, the bias in accounting-based cost of capital estimates is negatively correlated with recent stock price performance. The intuition for this bias is that accounting-based valuation models impute the cost of capital as the discount rate that equates current stock price with discounted expected future earnings. If recent stock returns have been high, and if analysts' forecasts of future earnings are too low due to sluggish updates of the information that has been recently impounded in stock price, the imputed discount rate will be artificially low in order to maintain the pricing equation.

Table 4 provides evidence that analysts' short- and long-term forecasts incorporate new information about future earnings more slowly than stock returns. To illustrate this point, we first rank the sample firms each year into deciles based on one-year stock returns leading up to the cost of capital measurement month of June. We further partition the most extreme top and bottom deciles into two equal-sized portfolios and report descriptive statistics for the resulting twelve portfolios. We assume that a large positive (negative) stock return indicates that investors have made substantial upward (downward) revisions in their expectations about a firm's future earnings. If analysts' revisions of earnings forecasts are less timely than stock returns, analysts' forecasts of future earnings are expected to be too low following large positive stock returns, and too high following large negative stock returns.

We measure whether analysts' forecasts are too high or too low by estimating one-year, two-year, and three-to-five-year-ahead forecast errors. One- and two-year-ahead forecast errors are based on analysts' mean (i.e., consensus) forecasts of one-year ahead and two-year ahead 
earnings, and are calculated as the analysts' mean earnings forecast minus actual earnings, scaled by assets per share. The scaling variable, assets per share, is the same for all three forecast errors, and is measured as of the same date as the book value of equity variable used in computing the cost of capital estimates (i.e., book value for the most recent fiscal year ending prior to June). ${ }^{11}$ We compute analysts' three-to-five-year-ahead forecast errors based on imputed estimates of analysts' three-, four-, and five-year-ahead earnings forecasts. Specifically, we impute analysts' three-year-ahead earnings forecasts by multiplying analysts' two-year-ahead earnings forecasts by analysts' long-term growth forecast. We impute four- and five-year-ahead forecasts in a similar manner. We then calculate the average three-to-five-year-ahead forecast error as the analysts' mean earnings forecast over this period minus actual average three-to-five-year-ahead earnings, and scale this error by assets per share. For each sample year, we compute the median values of the forecast errors for each portfolio ranking, and report the time-series median values in the table, which are less subject to outlier influences than the mean values. One- and two-year ahead analyst forecast errors are based on 34,488 observations. Three-to-five-year-ahead forecast errors are based on a smaller sample of 18,282 observations because we require future realized three-to-five-year-ahead earnings.

Table 4 indicates that the error in analysts' forecasts is negatively correlated with stock returns from the most recent year. When recent stock returns are ranked in the lowest $5 \%$ of the sample, analysts' mean forecasts are highly optimistically biased, with median errors (as a fraction of assets) of about $3 \%, 5.5 \%$, and $5.9 \%$ at the one-, two-, and three-to-five-year horizons. At the one- and two-year horizons, the forecast errors decline monotonically with the stock return portfolios, consistent with evidence in Lys and Sohn (1990) that analysts' forecasts

\footnotetext{
${ }^{11} \mathrm{We}$ also use price and actual earnings per share as deflators to calculate forecast errors and the inferences are similar.
} 
do not incorporate information in stock prices in a timely manner. When recent stock returns are in the highest $5 \%$ of the sample, analysts' mean forecasts exhibit a pessimistic bias at the oneyear horizon $(-0.5 \%)$ and almost no bias at the two-year horizon $(-0.1 \%)$. The absence of severe pessimistic bias in analysts' forecasts when stock returns are high is not surprising, given the widely documented optimism in analysts' mean forecasts during this sample period. The pattern of declining forecast errors across the return portfolios is also observed at the three-to-five-year horizon, except for the most extreme positive stock return portfolio, where the three-to-five-year forecast error rises to $4.8 \%$. This evidence of long-term analysts' forecast sluggishness complements the evidence in Lys and Sohn (1990) who show that short-term analysts' forecasts are sluggish.

Table 4 also reports the median cost of capital estimates in each of the stock return portfolios. As discussed earlier, sluggish analyst forecasts are expected to result in downward (upward) biased cost of capital estimates following large positive (negative) stock returns. Consistent with analyst forecast sluggishness, the accounting-based cost of capital estimates decline monotonically with the past stock return portfolios. The spread in the cost of capital estimates between the lowest and highest return portfolios is roughly $3 \%-4 \%$. As noted in section 1 , a portion of this relation can potentially be attributed to economic shocks to discount rates that are correlated with recent price changes. Emphasizing this concern that recent returns are correlated with important firm characteristics, the last three columns of Table 4 document variation in analyst following and analysts' short and long-term growth forecasts across the return portfolios. However, an economic relation between the true cost of capital and recent returns is unlikely to fully account for the documented relation between recent stock returns and implied cost of capital estimates for at least two reasons. First, as seen from Table 3, we fail to 
find a significant relation between the cost of capital estimates and future returns. If the association between the cost of capital estimates and recent returns is due solely to economic determinants, we would expect to find a significant positive relation between the cost of capital estimates and future returns. Second, as seen from Table 4, predictable variation in forecast errors suggests analyst sluggishness, which imparts a predictable error in the implied cost of capital estimates.

In Table 5, we provide additional direct evidence on sluggishness in analysts' forecasts, and how this sluggishness influences the relation between cost of capital estimates and recent stock returns. We estimate regressions of (1) analysts' short- and long-term forecast errors on recent one-year returns, and (2) cost of capital estimates on recent one-year stock returns. We also examine cross-sectional variation in this systematic measurement error by allowing the coefficient on recent returns to vary with firm size, book-to-market, and the logarithm of the number of analysts making forecasts. Similar to Table 3, we estimate the regressions annually, and tabulate the time-series average coefficients.

In Panel A of Table 5, we confirm the findings in Table 4 that the bias in analysts' shortand long-term forecast errors is negatively related to recent stock returns. In the model with oneyear-ahead forecast errors, FERR1, as the dependent variable, the coefficient on past return, $\mathrm{R}_{0}$, is -17.95 (t-statistic $=-6.57$ ), which is both statistically and economically significant. The coefficient magnitude implies an analyst forecast error of almost $18 \%$ of assets for a $100 \%$ stock return in the past one year, i.e., year 0 . The interaction variables indicate that the negative relation between forecast errors and recent returns is stronger for small firms and for firms with greater analyst following. Also note that the significance of the coefficient on past return, $R_{0}$, is robust to controlling for firm size, book-to-market, and analyst following as main effects. The 
negative relations between analyst forecast errors and firm size and book-to-market are consistent with the interpretation that analysts' forecasts are more optimistic for small firms and growth firms. In Section 4.3, we examine whether controlling for determinants of analyst optimism improves the implied cost of capital estimates.

The results in Panel B of Table 5 confirm that changes in accounting-based cost of capital estimates are negatively related to recent stock returns, with the OJN estimates exhibiting the strongest negative relation. For all of the accounting-based models, the negative relation between the change in cost of capital estimates and recent stock returns is stronger for smaller firms and firms that are followed by more analysts. For the GLS and CT estimates, the negative relation is also stronger for high book-to-market firms. In contrast to the highly significant relation between the change in implied cost of capital estimates and past returns, not surprisingly, the change in the Fama and French cost of capital estimates are not significantly related to recent stock performance and to the interaction variables. The Fama-French estimate does not rely on analyst forecasts and therefore is not subject to this particular bias.

Predictable error in the cost of capital estimates that is negatively correlated with recent stock returns causes a potential problem with our tests in Table 3 that examine the relation between cost of capital and future returns. Specifically, because recent stock returns are known to be positively correlated with one-year ahead stock returns (e.g., see the literature on return momentum by Jegadeesh 1990, Jegadeesh and Titman, 1993, and Fama and French, 1996), the predictable error is expected to induce a negative correlation between the accounting-based cost of capital estimates and one-year ahead stock returns. This makes it less likely that the hypothesized positive relation between future returns and the cost of capital estimates would be observed. 
To illustrate this confounding effect, we re-estimate the regressions in Table 3 using twoand three-year-ahead stock returns as dependent variables. Previous research documents the empirical regularity that stock return momentum generally does not persist for more than one year. Therefore, we do not expect the momentum-related bias to greatly influence tests of the relation between cost of capital estimates and two- and three-year-ahead returns. Consistent with this intuition, Gebhardt et al. and Gode and Mohanram (2003) sort stocks into quintiles based on cost of capital estimates and find that the relation between quintile cost of capital estimates and realized returns grows stronger over longer horizons. The tradeoff in these regressions is that the cost of capital estimates reflect firm-specific information that is current with respect to one-year future returns, but this information can be stale by the beginning of the measurement periods for the farther out future returns. The results are presented in Table 6 in a format similar to Table 3 .

Compared to the results in Table 3, the estimated slope coefficients for the longer-horizon tests are generally positive in sign. The most significant changes are observed for the GLS estimate, which exhibits the hypothesized positive relation with the two-year ahead and threeyear ahead (industry level) returns.

\subsection{ALTERNATIVE SPECIFICATIONS TO ECONOMETRICALLY MITIGATE THE BIAS}

The analysis in Section 4.2 indicates that analyst forecast sluggishness creates predictable measurement error in implied cost of capital estimates. The results also suggest that the relation between predictable bias in implied cost of capital estimates and return momentum is a contributing factor confounding our ability to find a significant positive relation between accounting-based cost of capital estimates and future returns. In this section, we explore alternative specifications that potentially mitigate these problems. 
For firms without recent stock price run-ups or run-downs, we do not expect analyst forecast sluggishness to cause substantial measurement error in the implied cost of capital estimates. Table 7 provides evidence that the implied cost of capital estimates are significantly positively related with future one-year stock returns for firms without substantial recent stock price changes. The regression specifications are identical to those in Table 3 except that they are estimated separately for three portfolios of firms ranked, by year, based on recent one-year stock returns. Since the subsamples employed in the regressions are identified annually on the basis of information available at the outset of the future one-year return (the dependent variable), our sampling procedure does not introduce econometric misspecifications.

Panels $\mathrm{A}$ and $\mathrm{C}$ of Table 7 indicate that for firms in the lowest and highest portfolios ranked by recent returns (median returns of $-21 \%$ and $+51 \%$, respectively), the implied cost of capital estimates and the Fama-French estimates fail to correlate positively with future returns. Panel B, on the other hand, documents that for firms in the middle portfolio of recent returns (median returns of 12\%), the GLS, CT, and finite Gordon implied cost of capital estimates exhibit a significant positive relation with future returns. Interestingly, the Fama-French cost of capital estimates are also significantly positively related with future returns. This latter result is not altogether unexpected given that we use five years of historical stock returns to estimate risk factor loadings in estimating the Fama-French cost of capital. When firms experience sharp oneyear changes in stock price, these historical factor loadings are likely to be more noisy estimates of current factor loadings.

Although the results in Table 7 suggest that both the implied and Fama-French cost of capital estimates are less misestimated for the subsample of firms without large recent stock price shocks, researchers and practitioners require techniques for estimating the cost of capital 
for the entire population of firms. As potential methods of mitigating the analyst sluggishness problem described above, we propose an augmented regression specification and an alternative estimation procedure for the accounting-based cost of capital models.

Our first approach is to improve the regression specification of future returns on the cost of capital estimates by including the most recent one-year stock return as a control variable. Because recent stock returns are correlated with both the bias in the cost of capital estimates and momentum in stock returns, we expect including recent stock returns will help control for the specification problem noted above. Table 8 reports the results of the augmented regression specification. Consistent with recent stock returns being negatively correlated with the error in the estimated cost of capital, and this error being negatively correlated with future returns, we expect and find the coefficient on recent stock returns to be significantly positive in all specifications. More importantly, in contrast to the findings in Table 3, the relation between oneyear-ahead returns and the GLS and finite Gordon cost of capital estimates is now significantly positive at the industry level and is marginally positive at the firm level.

As noted above, systematic optimism in analysts' forecasts is another potential source of error in estimating the cost of capital models. To check the influence of forecast optimism on our results, we re-estimate the Table 8 regressions and include firm size, book-to-market, and dispersion in analysts' forecasts (as proxied by the coefficient of variation in analysts' forecasts) as known determinants of forecast bias (see $\mathrm{Gu}$ and $\mathrm{Wu}, 2003$ for an example of empirical analysis that controls for determinants of forecast bias). Including these variables has no significant effect on the results reported in Table 8. Overall, the results in Table 8 provide additional evidence that accounting-based valuation models are potentially helpful in estimating 
firms' cost of capital, but that sluggishness in analysts' short- and long-term forecasts hinders the usefulness of these models.

In addition to this econometric approach to mitigating the sluggishness problem, we also propose alternative estimation procedures for the accounting-based cost of capital models that 1) allow analysts extra time to impound the information in recent price movements into their forecasts, and 2) remove stale analyst forecasts that have not been recently updated. To allow analysts extra time to impound new information in price, we estimate the accounting-based cost of capital models using stock prices at January instead of at June (i.e., approximately five months earlier than the stock price we use above). To remove stale forecasts, we re-compute consensus forecasts for each firm year, excluding the oldest one-third of analysts' forecasts each year. On average, the cut off for stale forecasts is roughly 75 days. All other aspects of the cost of capital estimation are identical to the previous analysis. In particular, we continue to use analysts' forecast data as of June, thereby allowing analysts approximately five extra months to resolve the sluggishness in their forecasts with respect to information that is embedded in January stock price. We use stock prices at the end of January because for many firms, preliminary book value information for the preceding fiscal year ending in December is known by the end of January.

Panels $\mathrm{A}$ and $\mathrm{B}$ of Table 9 report regression results of one-year future returns on accounting-based cost of capital estimates using the alternative estimation procedures. As in Table 3, we report time-series mean coefficients from annual regressions estimated at the firm and industry level. In Panel A, we compute the cost of capital estimates using stock price in January and analysts' consensus forecasts as of June. In contrast to the results in Table 3, when we allow analysts additional time to incorporate the new information in stock price, the firm level results now provide some evidence of a positive relation between future returns and 
accounting-based cost of capital estimates. The mean coefficients for all four of the models are positive, and the mean coefficients for the Gebhardt et al. and finite Gordon models are significantly positive. The mean coefficients at the industry level are insignificant and are very similar to those reported in Table 3. One potential reason for this mixed evidence is that measuring stock price at an earlier date comes at a cost. Specifically, analysts' forecasts in June will reflect some new information that is not impounded in price as of January. Further, it is possible that January stock price reflects information about book value for fiscal periods ending in December through May with error.

In Panel B, we continue to use January stock price in estimating the cost of capital, but now also exclude stale analysts' forecasts (oldest one-third of the empirical distribution) from the consensus forecast. The exclusion of stale forecasts has little effect on the firm-level regression results. At the industry level, however, the cost of capital estimates from the Gebhardt et al. model now exhibit a significant positive relation with future returns. Overall, the results in Table 9 provide at least modest evidence that our alternative estimation procedure is a promising method to overcome sluggishness in analysts' forecasts. These results also confirm our previous findings that the Gebhardt et al. measure outperforms the other implied cost of capital measures in terms of its positive correlation with future returns.

\section{Conclusion}

We evaluate various methods of estimating the cost of capital using realized stock returns as a metric. Previous literature documents that the Fama and French three-factor model leads to imprecise cost of capital estimates. Alternative implied cost of capital measures have been proposed, most of which rely on analysts' forecasts of short-term and long-term earnings. We show that the reliance on analyst forecasts poses a different set of problems for implied cost of 
capital estimates. Because analysts' forecasts are often sluggish with respect to information in stock returns, using a pricing equation to solve for the implied cost of capital leads to predictable bias in the cost of capital estimates. As a result, these implied cost of capital estimates are uncorrelated with future annual and monthly returns, as are the Fama and French three-factor estimates. The only exception is the Gebhardt et al. (2001) model, which exhibits a significant relation with future two-year- and three-year-ahead returns.

We propose two methods to mitigate the sluggishness problem that prevents the implied cost of capital from exhibiting a positive correlation with future annual returns. First, we estimate regressions of future returns on the cost of capital estimates and include recent one-year stock returns as a control variable. Because recent stock returns are correlated with the bias in the cost of capital estimates and with previously documented momentum in stock returns, we show that including recent stock returns in the specification helps control for the sluggishness problem, particularly with respect to the Gebhardt et al. (2001) and finite Gordon growth models. We also propose an alternative estimation procedure for the accounting-based cost of capital models that: 1) allow analysts extra time to impound the information in recent price movements into their forecasts, and 2) removes stale analysts' forecasts that have not been recently updated. Specifically, we estimate the implied cost of capital models using stock price measured approximately five months earlier than the date at which we measure analysts' consensus forecasts, and after removing stale forecasts that are more than about 75 days old. This procedure is most successful when using the Gebhardt et al., 2001 model, generating implied cost of capital estimates that are positively correlated with future returns in most partitionings of the data. 


\section{REFERENCES}

Abarbanell, J. S., 1991, Do analysts' earnings forecasts incorporate information in prior stock price changes? Journal of Accounting \& Economics 14, 147-165.

Abarbanell, J., Lehavy, R., 2002, Biased forecasts or biased earnings? The role of earnings management in explaining apparent optimism and inefficiency in analysts' earnings forecasts, working paper, University of North Carolina.

Ball, R., Kothari, S., 1989, Nonstationary expected returns: Implications for tests of market efficiency and serial correlation in returns, Journal of Financial Economics 25, 51-74.

Botosan, C., 1997, Disclosure level and the cost of equity capital, The Accounting Review 72, 323-349.

Botosan, C., Plumlee, M., 2002, Assessing the construct validity of alternative proxies for expected cost of equity capital, working paper, University of Utah.

Brown, L., 1997, Analyst forecasting errors: Additional evidence, Financial Analysts Journal 53, 81-88.

Brown, P., Foster, G., Noreen, E., 1985, Security analyst multi-year earnings forecasts and the capital markets, Studies in Accounting Research 21, American Accounting Association, Sarasota, Florida.

Campbell, J., Lo, A., MacKinlay, A., 1997, The Econometrics of Financial Markets (Princeton University Press, Princeton, NJ).

Claus, J., Thomas, J., 2001, Equity premia as low as three percent? Evidence from analysts' earnings forecasts for domestic and international stock markets, Journal of Finance 56, 1629-1666.

Dechow, P., Sloan, R., 1997, Returns to contrarian investment strategies: tests of naïve expectation hypotheses, Journal of Financial Economics 43, 3-27.

Easton, P., 2001, Forecasts of earnings and earnings growth, PEG ratios, and the implied internal rate of return on investments in stocks, working paper, Ohio State University.

Easton, P., Taylor, G., Shroff, P., Sougiannis, T., 2002, Using forecasts of earnings to simultaneously estimate growth and the rate of return on equity investment, Journal of Accounting Research 40, 657-676.

Fama, E., French, K., 1988, Permanent and temporary components of stock prices, Journal of Political Economy, 96, 246-273.

Fama, E., French, K., 1992, The cross-section of expected returns, Journal of Finance 47, 427465. 
Fama, E., French, K., 1993, Common risk factors in the returns on stocks and bonds, Journal of Financial Economics 33, 3-56.

Fama, E., French, K., 1996, Multifactor explanations of asset pricing anomalies, Journal of Finance 51, 55-84.

Fama, E., French, K., 1997, Industry costs of equity, Journal of Financial Economics 43, 153193.

Fama, E., MacBeth, J., 1973, Risk, return, and equilibrium: Empirical tests, Journal of Political Economy 38, 607-636.

French, K., Schwert, G., Stambaugh, R., 1987, Expected stock returns and stock market volatility, Journal of Financial Economics 19, 3-30.

Gebhardt, W., Lee, C., Swaminathan, B., 2001, Toward an implied cost of capital, Journal of Accounting Research 39, 135-176.

Gode, D., Mohanram, P., 2003, Implied cost of capital, working paper, New York University.

Gu, Z., Wu, J., 2003, Earnings skewness and analyst forecast bias, Journal of Accounting \& Economics 35, 5-29.

Jegadeesh, N., 1990, Evidence of predictable behavior of security returns, Journal of Finance 45, 881-898.

Jegadeesh, N., Titman, D., 1993, Returns to buying winners and selling losers: implications for stock market efficiency, Journal of Finance 48, 65-91.

Kothari, S., Shanken, J., Sloan, R., 1995, Another look at the cross-section of expected returns, Journal of Finance 50, 185-224.

LaPorta, R., 1996, Expectations and the cross-section of expected returns, Journal of Finance 51, $1715-42$.

Lim, T., 2001, Rationality and analysts' forecast bias, Journal of Finance 56, 369-385.

Lys, T., Sohn, S., 1990. The association between revisions of financial analysts' earnings forecasts and security price changes. Journal of Accounting and Economics 13, pp. 341363.

Ohlson, J., Juettner-Nauroth, B., 2000, Expected EPS and EPS growth as determinants of value, working paper, New York University.

Richardson, S., Teoh, S., Wysocki, P., 2003, Tracking analysts' forecasts over the Annual Earnings Horizon: Are Analysts' Forecasts Optimistic or Pessimistic?, Working paper, Massachusetts Institute of Technology. 
Shanken, J., 1985, Multivariate tests of the zero-beta CAPM, Journal of Financial Economics $14,327-348$.

Stickel, S., 1990, Predicting individual analyst earnings forecast, Journal of Accounting Research 28, 409-417. 
Table1: Summary of methods to calculate the cost of capital

\begin{tabular}{|c|c|c|c|}
\hline Model & $\mathrm{CC}$ & Equation used to obtain $\mathbf{r}_{0}$ & Key assumptions \\
\hline $\begin{array}{l}\text { Gebhardt, Lee and } \\
\text { Swaminathan }\end{array}$ & $r_{\text {gls }}$ & $\mathrm{P}_{0}=\mathrm{B}_{0}+\sum_{i=1}^{T-1} \frac{E_{0}\left[\left(R O E_{-}-r_{0}\right) B_{i-1}\right]}{\left(1+r_{0}\right)^{i}}+T V, T V=\frac{E_{0}\left[\left(R O E_{T}-r_{0}\right) B_{T-1}\right]}{r_{0}\left(1+r_{0}\right)^{T-1}}$ & $\begin{array}{l}\text { ROE fades linearly to median } \\
\text { industry ROE by } T=12 . \text { Year } \\
12 \text { residual income is earned } \\
\text { in perpetuity. }\end{array}$ \\
\hline Claus and Thomas & $r_{c t}$ & $\mathrm{P}_{0}=\mathrm{B}_{0}+\sum_{i=1}^{T} \frac{a e_{i}}{\left(1+r_{0}\right)^{i}}+T V, T V=\frac{a e_{T}(1+g)}{\left(r_{0}-g\right)\left(1+r_{0}\right)^{T}}$ & $\begin{array}{l}\text { Growth after } \mathrm{T}=5 \text { is set equal } \\
\text { to the inflation rate, } \mathrm{g}=\mathrm{r}_{\mathrm{f}}- \\
3 \% \text {. }\end{array}$ \\
\hline Finite Horizon Gordon & $r_{\text {gordon }}$ & $\mathrm{P}_{0}=\sum_{i=1}^{T} \frac{E_{0}\left[d_{i}\right]}{\left(1+r_{0}\right)^{i}}+\frac{E_{0}\left[\text { FEPS }_{1+T}\right]}{r_{0}\left(1+r_{0}\right)^{T}}$ & ROE reverts to $r_{0}$ after $T=4$. \\
\hline $\begin{array}{l}\text { Gode and Mohanram } \\
\text { (Ohlson and Juettner- } \\
\text { Nauroth) }\end{array}$ & $\mathrm{r}_{\mathrm{ojn}}$ & $\mathrm{P}_{0}=\frac{F E P S_{1}}{r_{0}}+\frac{F E P S_{2}-F E P S_{1}-r_{0}\left(F E P S_{1}-d p s_{1}\right]}{r_{0}\left(r_{0}-g\right)}$ & $\begin{array}{l}\text { The long-term growth rate } g= \\
r_{f}-3 \% .\end{array}$ \\
\hline Fama and French & $\mathrm{r}_{\mathrm{ff}}$ & $\mathrm{E}\left(\mathrm{R}_{0}\right)=\mathrm{R}_{\mathrm{f} 0}+\mathrm{b}_{0}\left[\mathrm{R}_{\mathrm{m}}-\mathrm{R}_{\mathrm{f}}\right]+\mathrm{s}_{0} \mathrm{SML}+\mathrm{h}_{0} \mathrm{HML}$ & \\
\hline
\end{tabular}

\section{Notes:}

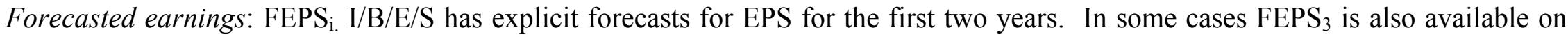
IBES. If not, we use the 5-year long-term growth rate, $\mathrm{FG}_{5}$, to compute $\mathrm{FEPS}_{3}$. We also use FG5 to calculate $\mathrm{FEPS}_{4}$ and $\mathrm{FEPS}_{5}$ if a model calls for explicit forecasts for these later years.

Growth rate from Year 3 to $T$, the terminal period: In Gebhardt et al., we assume T = 12, and ROE fades linearly to median industry ROE by Year 12 (calculated using ten years of past data for 48 Fama and French industries, excluding loss firms). In the finite 
horizon Gordon model, we assume that $\mathrm{T}=4$, and ROE reverts back to $\mathrm{r}_{0}$ after Year 4. In Claus and Thomas, $\mathrm{T}=5$, and the growth rate between 3 and 5 is essentially FG5, the five-year growth rate from I/B/E/S.

Growth rate beyond T: $\mathrm{g}$ is the growth rate of abnormal earnings beyond T, the year when the terminal value is calculated. The models differ in their assumptions about the earnings growth rate beyond T. In GLS and the finite Gordon model, $T$ terminal earnings are treated as a perpetuity. In Claus and Thomas, terminal growth after Year 5 is assumed to equal the inflation rate, which is set equal to $\mathrm{g}=\mathrm{r}_{\mathrm{f}}-3 \%$, under the assumption that that the real risk-free interest rate is always 3\%. Gode and Mohanram make similar assumptions.

Return on equity: $\mathrm{ROE}_{\mathrm{i}}=$ Earnings $_{\mathrm{i}} / \mathrm{B}_{\mathrm{i}-1}$.

Forecasted book value per share: $\mathrm{B}_{\mathrm{i}}=\mathrm{B}_{\mathrm{i}-1}+$ FEPS $_{\mathrm{i}}-\mathrm{dps}_{\mathrm{i}}$,

Forecasted dividend per share: $\mathrm{dps}_{\mathrm{i}}=\mathrm{k}^{*} \mathrm{FEPS}_{\mathrm{i}}$, where $\mathrm{k}$ is estimated using the current dividend payout ration, $\mathrm{k}=($ dividends paid $) /$ earnings. If earnings are negative, we divide the dividends paid by $(0.06 *$ total assets $)$ to derive an estimate of the payout ratio. We winsorize the value of $\mathrm{k}$ to be between 0 and 1 .

Cost of capital: $\mathrm{r}_{0}$ is the value that equates $\mathrm{P}_{0}$ with the right-hand side expressions for the implied cost of capital models. Estimated cost of capital is restricted to be between 0 and $50 \%$.

The three factors in the Fama and French model, SML, HML, $\mathrm{R}_{\mathrm{m}}$ are obtained from Kenneth French's website. The loadings on the factors, $\mathrm{b}, \mathrm{s}$, and h, are slope coefficients estimated from a rolling 5-year regression model:

$\mathrm{R}_{\mathrm{i}}-\mathrm{R}_{\mathrm{f}}=\mathrm{a}_{\mathrm{i}}+\mathrm{b}_{\mathrm{i}}\left[\mathrm{R}_{\mathrm{m}}-\mathrm{R}_{\mathrm{f}}\right]+\mathrm{s}_{\mathrm{i}} \mathrm{SML}+\mathrm{h}_{\mathrm{i}} \mathrm{HML}+\mathrm{e}_{\mathrm{i}}$. 


\section{Table2: Descriptive statistics}

Panel A shows the year-by-year implied cost of capital measured as of June $30^{\text {th }}$ of each year from 1982 to 2000 . Refer to Table 1 for notations and procedures to calculate the five cost of capital measures. We also present mean one-year realized returns calculated over the year starting from July $1^{\text {st }}$ after the June $30^{\text {th }}$ measurement date for the cost of capital measures. Panel B presents average annual cross correlations between the five cost of capital measures. We calculate correlations for each year from 1982 to 2000, and present the time-series means of these yearly correlations.

Panel A: Descriptive statistics of Cost of capital measures

\begin{tabular}{|c|c|c|c|c|c|c|c|}
\hline \multirow[t]{2}{*}{ Year } & \multirow{2}{*}{$\begin{array}{l}\text { No. of } \\
\text { obs. }\end{array}$} & \multicolumn{5}{|c|}{ Average estimated cost of capital, in \% } & \multirow{2}{*}{$\begin{array}{l}\text { Mean one-year-ahead } \\
\text { realized return }\end{array}$} \\
\hline & & $\mathbf{r}_{\mathrm{gls}}$ & $\mathbf{r}_{\mathrm{ct}}$ & $\mathbf{r}_{\text {gordon }}$ & $r_{\text {ojn }}$ & $\mathbf{r}_{\mathrm{ff}}$ & \\
\hline 1982 & 1,045 & 14.7 & 18.4 & 16.6 & 21.1 & 21.1 & 88.6 \\
\hline 1983 & 1,244 & 10.7 & 12.9 & 10.8 & 16.7 & 18.2 & -12.3 \\
\hline 1984 & 1,516 & 12.7 & 15.8 & 13.5 & 19.2 & 19.2 & 25.0 \\
\hline 1985 & 1,551 & 11.4 & 13.0 & 11.4 & 16.0 & 16.7 & 31.5 \\
\hline 1986 & 1,537 & 9.8 & 10.3 & 9.1 & 13.5 & 15.7 & 11.9 \\
\hline 1987 & 1,688 & 9.9 & 10.6 & 9.1 & 14.0 & 14.5 & -5.1 \\
\hline 1988 & 1,607 & 11.1 & 11.9 & 10.7 & 14.4 & 14.4 & 16.2 \\
\hline 1989 & 1,680 & 10.8 & 11.2 & 10.1 & 13.5 & 16.5 & 7.9 \\
\hline 1990 & 1,692 & 10.9 & 11.6 & 10.4 & 14.4 & 16.4 & 5.8 \\
\hline 1991 & 1,769 & 10.5 & 11.1 & 9.7 & 14.2 & 13.7 & 17.1 \\
\hline 1992 & 1,893 & 10.2 & 10.5 & 9.6 & 13.8 & 12.9 & 22.4 \\
\hline 1993 & 2,129 & 9.7 & 9.5 & 9.0 & 12.7 & 12.8 & 4.3 \\
\hline 1994 & 2,447 & 9.9 & 10.2 & 9.3 & 13.3 & 14.4 & 22.8 \\
\hline 1995 & 2,647 & 9.9 & 9.9 & 9.3 & 12.8 & 16.7 & 23.8 \\
\hline 1996 & 2,814 & 9.3 & 9.5 & 8.5 & 12.4 & 15.6 & 20.3 \\
\hline 1997 & 3,114 & 9.0 & 9.1 & 8.2 & 12.2 & 15.4 & 19.3 \\
\hline 1998 & 3,165 & 8.9 & 8.8 & 8.2 & 12.0 & 15.4 & 2.1 \\
\hline 1999 & 3,008 & 9.6 & 9.7 & 8.9 & 12.6 & 15.7 & 10.4 \\
\hline 2000 & 2,585 & 9.9 & 10.7 & 9.6 & 13.0 & 18.1 & 18.6 \\
\hline Mean & & 10.5 & 11.3 & 10.1 & 14.3 & 16.0 & 17.4 \\
\hline Median & & 9.9 & 10.6 & 9.6 & 13.5 & 15.7 & 17.1 \\
\hline
\end{tabular}

Panel B: Cross-correlations between implied cost of capital estimates (time-series means of annual pairwise cross-sectional correlations)

\begin{tabular}{cccccc}
\hline & $\mathbf{r}_{\text {gls }}$ & $\mathbf{r}_{\mathbf{c t}}$ & $\mathbf{r}_{\text {gordon }}$ & $\mathbf{r}_{\mathbf{o j n}}$ & $\mathbf{r}_{\mathbf{f f}}$ \\
\hline $\mathbf{r}_{\text {gls }}$ & 1 & & & & \\
$\mathbf{r}_{\mathbf{c t}}$ & 0.720 & 1 & & & \\
$\mathbf{r}_{\text {gordon }}$ & 0.803 & 0.871 & 0.655 & 1 & 1 \\
$\mathbf{r}_{\mathbf{0 j n}}$ & 0.501 & 0.645 & 0.144 & 0.136 & 1 \\
$\mathbf{r}_{\text {ff }}$ & 0.145 & 0.126 & 0.136 & \\
\hline \hline
\end{tabular}




\section{Table 3: Regressions of future annual returns on cost-of-capital measures}

This table provides the time-series statistics of the slope coefficients from the following regression: $R_{1}=\alpha_{1}+\beta_{1} r_{i}+\varepsilon_{1}$. The dependent variable, $R_{1}$, is one-yearahead stock returns starting from July $1^{\text {st }}$ after the June $30^{\text {th }}$ measurement date for the cost of capital measures. The cost of capital measures, $r_{\text {gls, }}, r_{c t}, r_{\text {gordon, }} r_{\text {ojn }}$, and $\mathrm{r}_{\mathrm{ff}}$ are defined in Table 1 and are estimated as of June $30^{\text {th }}$ each year. We run the cross-sectional regression for each year, and present the time-series descriptive statistics of the slope coefficients. We perform the regressions both at a firm level and at an industry level. The industry portfolios are formed based on the Fama and French classification of 48 industries.

Summary statistics of $\beta_{1}$ from regressions of one-year ahead returns on cost of capital measures: $R_{1}=\alpha_{1}+\beta_{1} \mathbf{r}_{i}+\varepsilon$

\begin{tabular}{|c|c|c|c|c|c|c|c|c|c|c|}
\hline & \multicolumn{5}{|c|}{ Firm level } & \multicolumn{5}{|c|}{ Industry level } \\
\hline & $\mathbf{r}_{\mathrm{gls}}$ & $\mathbf{r}_{\mathrm{ct}}$ & $\mathbf{r}_{\text {gordon }}$ & $\mathbf{r}_{\mathbf{o j n}}$ & $\mathbf{r}_{\mathrm{ff}}$ & $\mathbf{r}_{\text {gls }}$ & $\mathbf{r}_{\mathrm{ct}}$ & $\mathbf{r}_{\text {gordon }}$ & $\mathbf{r}_{\mathbf{o j n}}$ & $\mathbf{r}_{\mathbf{f f}}$ \\
\hline Time-series mean & 0.12 & -0.24 & 0.05 & -0.37 & 0.10 & 0.21 & -0.83 & 0.14 & -0.58 & -0.14 \\
\hline Std Error & 0.51 & 0.38 & 0.44 & 0.29 & 0.14 & 0.79 & 0.93 & 0.79 & 0.55 & 0.26 \\
\hline t-stat & 0.23 & -0.65 & 0.11 & -1.26 & 0.69 & 0.26 & -0.89 & 0.18 & -1.07 & -0.54 \\
\hline Time-series median & -0.13 & -0.31 & -0.31 & -0.52 & -0.05 & 1.17 & -0.51 & 0.16 & -0.57 & -0.33 \\
\hline Mean adj. $\mathrm{R}^{2}$ in $\%$ & 1.8 & 1.0 & 1.9 & 1.1 & 0.5 & 4.5 & 5.2 & 6.3 & 2.9 & 4.1 \\
\hline
\end{tabular}


Table 4: The relation between lagged annual returns, cost of capital estimates, and analysts' forecast errors One-year-, two-year-, and three-to-five-year-ahead analysts' forecast errors. Portfolios ranked on one-year lagged returns, $\mathbf{R}_{0}$.

The portfolios are formed on June $30^{\text {th }}$ of each year ranked by $\mathrm{R}_{0}$, stock returns measured over the one-year period leading up to the June $30^{\text {th }}$ measurement date for the cost of capital measures. $\mathrm{R}_{1}$ is one-year-ahead stock returns starting from July $1^{\text {st }}$ after the June $30^{\text {th }}$ measurement date for the cost of capital measures. The cost of capital measures, $r_{\text {gls }}, r_{c t}, r_{\text {gordon, }} r_{\text {ojn }}$, and $r_{f f}$ are defined in Table 1 and are estimated as of June $30^{\text {th }}$ each year. FG5 is the long-term growth rate reported by $\mathrm{I} / \mathrm{B} / \mathrm{E} / \mathrm{S}$ as of the cost of capital measurement month of June. St $\mathrm{g}$ is the estimated $\mathrm{I} / \mathrm{B} / \mathrm{E} / \mathrm{S}$ forecasted short term growth rate as of the cost of capital measurement month of June, and is computed as $\left(\mathrm{FEPS}_{2}-\mathrm{FEPS}_{1}\right) / \mathrm{FEPS}_{1}$, where FEPS 1 (FEPS $)$ is the mean forecasted EPS for the first (second) fiscal year ending after June $30^{\text {th }}$ of the cost of capital measurement month. FERR1 is the analyst forecast error for the first fiscal year ending after June $30^{\text {th }}$ of the cost of capital measurement month, and is calculated as $\left(\right.$ FEPS $_{1}-$ Actual EPS 1$) /$ Assets per share, where Assets per share is measured as of the most recent fiscal year ending on or before the cost of capital measurement month. FERR2 is the forecast error for the second fiscal year ending after June $30^{\text {th }}$ of cost of capital measurement month, and is estimated analogously to FERR1. FERR3 5 is the average forecast error for the third, fourth, and fifth fiscal years ending after June $30^{\text {th }}$ of the cost of capital measurement month. We compute analysts' three-, four- and five-year-ahead forecast errors based on imputed estimates of analysts' three-, four-, and five-year-ahead earnings forecasts. We impute analysts' three-year-ahead earnings forecasts by multiplying analysts' two-year ahead earnings forecasts by analysts' long-term growth forecast. We impute four-year and five-year-ahead forecasts in a similar manner. We then compute the average three-tofive-year-ahead forecast error as the mean analyst forecast over this period minus actual average earnings over this period, and scale this error by assets per share, where Assets per share is measured as of the most recent fiscal year ending on or before the cost of capital measurement month. We compute median values of the reported variables each year for each portfolio ranking. The table reports the time-series median values of the by-year median values. One-year and two-yearahead analyst forecast errors are based on 34,488 observations. Three-to-five-year-ahead analyst forecast errors are based on a smaller sample of 18,282 observations because we require future realized three-to-five-year-ahead earnings.

\begin{tabular}{|c|c|c|c|c|c|c|c|c|c|c|c|c|c|c|}
\hline \multicolumn{2}{|c|}{ Portfolios } & \multirow{2}{*}{\begin{tabular}{c|}
$\mathbf{R}_{\mathbf{0}}$ \\
-49.4
\end{tabular}} & \multirow{2}{*}{$\begin{array}{c}\mathbf{R}_{\mathbf{1}} \\
-3.4\end{array}$} & \multirow{2}{*}{$\begin{array}{c}\text { FERR1 } \\
3.0\end{array}$} & \multirow{2}{*}{$\begin{array}{c}\text { FERR2 } \\
5.5\end{array}$} & \multirow{2}{*}{$\begin{array}{c}\text { FERR3_5 } \\
5.9\end{array}$} & \multirow{2}{*}{$\frac{\mathbf{r}_{\text {gls }}}{12.3}$} & \multirow{2}{*}{$\frac{\mathbf{r}_{\mathbf{c t}}}{12.1}$} & \multirow{2}{*}{$\frac{\mathbf{r}_{\text {gordon }}}{11.5}$} & \multirow{2}{*}{$\frac{\mathbf{r}_{\mathbf{0 j n}}}{16.8}$} & \multirow{2}{*}{$\frac{\mathbf{r}_{\mathrm{ff}}}{14.1}$} & \multirow{2}{*}{$\begin{array}{c}\text { FG5 } \\
18.5\end{array}$} & \multirow{2}{*}{$\frac{\text { St g }}{41.9}$} & \multirow{2}{*}{$\frac{\text { \#Analyst }}{5}$} \\
\hline 1 & Bot $5 \%$ & & & & & & & & & & & & & \\
\hline 2 & $5 \%-10 \%$ & -33.3 & 4.1 & 1.6 & 3.1 & 3.5 & 11.5 & 11.2 & 10.5 & 15.1 & 15.8 & 16.5 & 31.0 & 6 \\
\hline 3 & $10-20 \%$ & -19.0 & 7.5 & 0.7 & 2.1 & 3.2 & 11.1 & 10.9 & 10.1 & 14.1 & 15.0 & 14.6 & 24.6 & 7 \\
\hline 4 & $20-30 \%$ & -7.2 & 10.9 & 0.5 & 1.4 & 2.1 & 10.6 & 10.3 & 9.6 & 13.5 & 14.3 & 13.4 & 19.5 & 8 \\
\hline 5 & $30-40 \%$ & 2.8 & 12.1 & 0.2 & 0.9 & 1.9 & 10.2 & 10.1 & 9.3 & 12.7 & 13.9 & 12.6 & 17.3 & 8 \\
\hline 6 & $40-50 \%$ & 11.3 & 12.8 & 0.1 & 0.7 & 1.4 & 9.9 & 10.1 & 9.3 & 12.6 & 13.8 & 12.6 & 16.2 & 9 \\
\hline 7 & $50-60 \%$ & 18.3 & 16.2 & 0.0 & 0.6 & 1.0 & 9.6 & 9.9 & 9.0 & 12.4 & 13.9 & 12.7 & 14.6 & 9 \\
\hline 8 & $60-70 \%$ & 25.2 & 13.8 & 0.0 & 0.2 & 1.5 & 9.6 & 9.6 & 8.9 & 12.1 & 14.1 & 12.9 & 15.2 & 9 \\
\hline 9 & $70-80 \%$ & 34.2 & 11.3 & 0.0 & 0.1 & 1.0 & 9.3 & 9.6 & 8.6 & 12.3 & 13.9 & 13.1 & 16.5 & 8 \\
\hline 10 & $80-90 \%$ & 56.4 & 11.5 & -0.1 & 0.0 & 1.7 & 9.0 & 9.4 & 8.1 & 12.0 & 14.2 & 14.6 & 18.6 & 7 \\
\hline 11 & $90-95 \%$ & 78.7 & 12.3 & -0.2 & 0.1 & 1.5 & 8.8 & 9.3 & 7.7 & 12.2 & 15.7 & 16.8 & 22.4 & 7 \\
\hline 12 & $>95 \%$ & 122.1 & 7.1 & -0.5 & -0.1 & 4.8 & 8.5 & 9.2 & 7.2 & 12.1 & 15.2 & 20.0 & 26.4 & 6 \\
\hline
\end{tabular}


Table 5: Lagged returns and changes in the cost of capital estimates

In Panel A, the dependent variables are the one-year-, two-year-, and three-to-five-year-ahead forecast errors. FERR1 is the analyst forecast error for the first fiscal

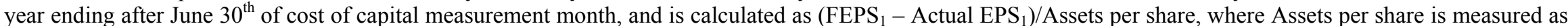
of the most recent fiscal year ending on or before the cost of capital measurement month. FERR2 is the forecast error for the second fiscal year ending after June $30^{\text {th }}$ of cost of capital measurement month, and is estimated analogously to FERR1. FERR3 5 is the average forecast error for the third, fourth, and fifth fiscal years ending after June $30^{\text {th }}$ of cost of capital measurement month. We compute analysts' three-, four- and five-year-ahead forecast errors based on imputed estimates of analysts' three-, four-, and five-year-ahead earnings forecasts. We impute analysts' three-year-ahead earnings forecasts by multiplying analysts' two-year-ahead earnings forecasts by analysts' long-term growth forecast. We impute four-year and five-year-ahead forecasts in a similar manner. We then compute the average three-to-five-year-ahead forecast error as the mean analyst forecast over this period minus actual average earnings over this period, and scale this error by assets per share, where Assets per share is measured as of the most recent fiscal year ending on or before the cost of capital measurement month. $\mathrm{R}_{0}$ is the stock return measured from July to June during the one-year period over which the change in cost of capital variable is computed. Size is the log of the market value of equity. Book-tomarket is the book value of equity divided by the market value of equity. Log(\#analysts) is the log of the number of analysts following the firm. Size and $\log$ (\#analysts) are computed as of June just prior to the beginning of the return measurement period for $\mathrm{R}_{0}$. Book-to-market is computed as of the most recent fiscal period prior to the June month that precedes the beginning of the return measurement period for $\mathrm{R}_{0}$. We run the cross-sectional regression for each year, and present the time-series average slope coefficients. In Panel B, the dependent variable is the change in the cost of capital estimate, computed as the cost of capital estimate as of June minus the cost of capital estimate as of June in the previous year. The cost of capital measures, $r_{\text {glss, }}, r_{c t}, r_{\text {gordon, }} r_{\text {ojn, }}$ and $r_{f f}$ are defined in Table 1 and are estimated as of June $30^{\text {th }}$ each year.

\section{Panel A: Regressions of forecast errors on lagged annual return and firm characteristics}

\begin{tabular}{|c|c|c|c|c|c|c|}
\hline \multirow[t]{2}{*}{ Dep. variable } & \multicolumn{2}{|c|}{ FERR1 } & \multicolumn{2}{|c|}{ FERR2 } & \multicolumn{2}{|c|}{ FERR3 5} \\
\hline & Coef. & t-stat & Coef. & t-stat & Coef & t-stat \\
\hline intercept & 10.74 & 7.81 & 22.69 & 10.40 & 28.44 & 10.28 \\
\hline $\mathrm{R}_{0}$ & -17.95 & -6.57 & -20.10 & -5.23 & -19.34 & -3.02 \\
\hline $\mathrm{R}_{0} *$ Size & 0.89 & 5.97 & 1.05 & 5.08 & 1.20 & 2.94 \\
\hline $\mathrm{R}_{0} *$ Book-to-market & -0.04 & -0.91 & 0.22 & 0.86 & -0.64 & -0.73 \\
\hline $\mathrm{R}_{0} * \log$ (\#analysts) & -0.88 & -4.60 & -1.57 & -4.99 & -2.39 & -2.64 \\
\hline Size & -0.51 & -6.89 & -1.05 & -8.62 & -1.31 & -8.06 \\
\hline Book-to-market & -0.02 & -7.89 & -0.05 & -5.37 & 0.18 & 0.49 \\
\hline $\log$ (\#analysts) & 0.29 & 3.07 & 0.66 & 4.34 & 1.10 & 2.82 \\
\hline Mean adj. $\mathrm{R}^{2}$ in $\%$ & 13.0 & & 8.3 & & 4.4 & \\
\hline
\end{tabular}


Panel B: Regressions of the change in cost of capital $\left(\Delta r_{i}\right)$ on lagged annual return and firm characteristics

\begin{tabular}{|c|c|c|c|c|c|c|c|c|c|c|}
\hline \multirow[t]{2}{*}{ Dep. variable } & \multicolumn{2}{|c|}{$\Delta \mathbf{r}_{\text {gls }}$} & \multicolumn{2}{|c|}{$\Delta \mathbf{r}_{\mathrm{ct}}$} & \multicolumn{2}{|c|}{$\Delta \mathbf{r}_{\text {gordon }}$} & \multicolumn{2}{|c|}{$\Delta \mathbf{r}_{\mathbf{o j n}}$} & \multicolumn{2}{|c|}{$\Delta \mathbf{r}_{\mathrm{ff}}$} \\
\hline & Coef. & t-stat & Coef. & t-stat & Coef & t-stat & Coef & t-stat & Coef & t-stat \\
\hline intercept & 1.39 & 2.66 & 0.29 & 0.25 & 0.25 & 0.28 & 1.42 & 2.29 & -1.36 & -1.19 \\
\hline $\mathrm{R}_{0} *$ Size & 0.31 & 6.30 & 0.33 & 3.77 & 0.31 & 3.91 & 0.82 & 9.42 & 0.10 & 1.09 \\
\hline $\mathrm{R}_{0} *$ Book-to-market & -0.07 & -4.07 & -0.10 & -1.90 & 0.00 & 0.08 & 0.02 & 0.33 & -0.01 & -0.50 \\
\hline Size & -0.07 & -2.77 & -0.03 & -0.61 & -0.02 & -0.52 & -0.09 & -2.25 & 0.02 & 0.35 \\
\hline Book-to-market & 0.00 & 0.55 & -0.01 & -1.25 & -0.01 & -1.43 & -0.01 & -1.93 & 0.00 & 0.48 \\
\hline $\log$ (\#analysts) & 0.11 & 2.16 & 0.08 & 1.20 & 0.09 & 1.03 & 0.11 & 1.66 & 0.20 & 1.51 \\
\hline
\end{tabular}


Table 6: Regressions of two-year and three-year future returns on cost-of-capital measures

This table provides the time-series statistics of the slope coefficients from the following regression: $R_{i}=\alpha_{i}+\beta_{i} r_{i}+\varepsilon_{i .}$. The dependent variable, $R_{2}$, is the twoyear-ahead annual stock return starting from July $1^{\text {st }}$ one year after the June $30^{\text {th }}$ measurement date for the cost of capital measures. The dependent variable, $R_{3}$, is the three-year-ahead annual stock return starting from July $1^{\text {st }}$ two years after the June $30^{\text {th }}$ measurement date for the cost of capital measures. We run the crosssectional regression for each year, and present the time-series descriptive statistics of the slope coefficients. We perform the regressions both at a firm level and at an industry level. The industry portfolios are formed based on the Fama and French classification of 48 industries. The cost of capital measures, $r_{\mathrm{gls}}, \mathbf{r}_{\mathrm{ct}}, \mathrm{r}_{\mathrm{gordon}}$ $r_{\mathrm{ojn}}$, and $\mathrm{r}_{\mathrm{ff}}$ are defined in Table 1 and are estimated as of June $30^{\text {th }}$ each year.

Panel A: Summary statistics of $\beta_{2}$ from two-year future return regressions: $R_{2}=\alpha_{2}+\beta_{2} \mathbf{r}_{\mathbf{i}}+\varepsilon$

\begin{tabular}{|c|c|c|c|c|c|c|c|c|c|c|}
\hline & \multicolumn{5}{|c|}{ Firm level } & \multicolumn{5}{|c|}{ Industry level } \\
\hline & $\mathbf{r}_{\mathrm{gls}}$ & $\mathbf{r}_{\mathrm{ct}}$ & $\mathbf{r}_{\text {gordon }}$ & $\mathbf{r}_{\mathbf{o j n}}$ & $\mathbf{r}_{\mathrm{ff}}$ & $\mathbf{r}_{\text {gls }}$ & $\mathbf{r}_{\mathrm{ct}}$ & $\mathbf{r}_{\text {gordon }}$ & $r_{\mathbf{o j n}}$ & $\mathbf{r}_{\mathrm{ff}}$ \\
\hline Time-series mean & 0.81 & 0.38 & 0.54 & 0.20 & 0.06 & 1.28 & 0.04 & 0.60 & -0.11 & -0.05 \\
\hline Std Error & 0.33 & 0.34 & 0.33 & 0.26 & 0.06 & 0.58 & 0.79 & 0.56 & 0.53 & 0.30 \\
\hline t-stat & 2.47 & 1.12 & 1.62 & 0.75 & 0.87 & 2.21 & 0.05 & 1.06 & -0.21 & -0.17 \\
\hline Time-series median & 0.74 & 0.31 & 0.40 & 0.15 & -0.01 & 1.66 & 0.61 & 0.95 & -0.82 & -0.25 \\
\hline Mean adj. $\mathrm{R}^{2}$ in $\%$ & 0.9 & 0.7 & 1.0 & 0.6 & 0.2 & 5.0 & 4.2 & 4.5 & 2.2 & 2.8 \\
\hline
\end{tabular}

Panel B: Summary statistics of $\beta_{3}$ from three-year future return regressions: $\mathbf{R}_{\mathbf{3}}=\alpha_{3}+\beta_{3} \mathbf{r}_{\mathbf{i}}+\varepsilon$

\begin{tabular}{|c|c|c|c|c|c|c|c|c|c|c|}
\hline & \multicolumn{5}{|c|}{ Firm level } & \multicolumn{5}{|c|}{ Industry level } \\
\hline & $\mathbf{r}_{\text {gls }}$ & $\mathbf{r}_{\mathrm{ct}}$ & $\mathbf{r}_{\text {gordon }}$ & $\mathbf{r}_{\mathbf{o j n}}$ & $\mathbf{r}_{\mathbf{f f}}$ & $\mathbf{r}_{\text {gls }}$ & $\mathbf{r}_{\mathrm{ct}}$ & $\mathbf{r}_{\text {gordon }}$ & $\mathbf{r}_{\mathbf{o j n}}$ & $\mathbf{r}_{\mathrm{ff}}$ \\
\hline Time-series mean & 0.41 & 0.08 & 0.11 & 0.20 & 0.04 & 1.36 & 1.18 & 1.01 & 0.57 & 0.27 \\
\hline Std Error & 0.41 & 0.30 & 0.35 & 0.26 & 0.09 & 0.52 & 0.77 & 0.61 & 0.52 & 0.25 \\
\hline t-stat & 0.98 & 0.26 & 0.31 & 0.78 & 0.47 & 2.65 & 1.54 & 1.66 & 1.10 & 1.07 \\
\hline Time-series median & 0.63 & 0.16 & 0.44 & 0.05 & 0.01 & 1.90 & 2.38 & 1.42 & 0.94 & 0.31 \\
\hline Mean adj. $\mathrm{R}^{2}$ in $\%$ & 0.7 & 0.4 & 0.6 & 0.5 & 0.3 & 3.1 & 3.8 & 3.9 & 1.7 & 2.5 \\
\hline
\end{tabular}




\section{Table 7: Regressions of future returns on cost-of-capital measures for Low, Medium, and High lagged return portfolios}

This table provides the time-series statistics of the slope coefficients of the following regression: $R_{1}=\alpha_{1}+\beta r_{i}$ $+\varepsilon_{1}$. The regressions are run at firm level for each of the three portfolios: Low, Medium, and High. The portfolios are formed each year based on the lagged annual return, $\mathrm{R}_{0}$, which is the stock return measured from July to June during the one-year period over which the change in cost of capital variable is computed. We run cross-sectional regressions each year within each portfolio, and report the time-series statistics for the different return portfolios in Panels A through C. The cost of capital measures, $r_{\mathrm{gls}}, \mathrm{r}_{\mathrm{ct}}, \mathrm{r}_{\mathrm{gordon}}, \mathrm{r}_{\mathrm{ojn}}$, and $\mathrm{r}_{\mathrm{ff}}$ are defined in Table 1 and are estimated as of June $30^{\text {th }}$ each year.

Panel A: Summary statistics of $\beta$ for Portfolio 'Low'

\begin{tabular}{cccccc}
\hline \hline & $\mathbf{r}_{\text {gls }}$ & $\mathbf{r}_{\mathbf{c t}}$ & $\mathbf{r}_{\text {gordon }}$ & $\mathbf{r}_{\mathbf{o j n}}$ & $\mathbf{r}_{\mathbf{f f}}$ \\
\hline Time-series mean & -0.155 & -0.291 & 0.066 & -0.393 & -0.017 \\
Std Error & 0.480 & 0.379 & 0.438 & 0.235 & 0.090 \\
t-stat & -0.322 & -0.767 & 0.151 & -1.668 & -0.190 \\
Time-series median & -0.179 & -0.221 & 0.460 & -0.586 & -0.061 \\
Mean adj. $\mathrm{R}^{2}$ in \% & 0.010 & 0.018 & 0.023 & 0.016 & 0.004 \\
\hline \hline
\end{tabular}

Panel B: Summary statistics of $\beta$ for Portfolio 'Medium'

\begin{tabular}{clllll}
\hline \hline & $\mathbf{r}_{\text {gls }}$ & $\mathbf{r}_{\mathbf{c t}}$ & $\mathbf{r}_{\text {gordon }}$ & $\mathbf{r}_{\mathbf{o j n}}$ & $\mathbf{r}_{\mathbf{f f}}$ \\
\hline Time-series mean & 1.127 & 0.807 & 0.892 & 0.045 & 0.227 \\
Std Error & 0.400 & 0.334 & 0.353 & 0.196 & 0.103 \\
t-stat & 2.818 & 2.415 & 2.526 & 0.228 & 2.196 \\
Time-series median & 1.165 & 0.899 & 0.828 & 0.003 & 0.183 \\
Mean adj. $\mathrm{R}^{2}$ in \% & 0.018 & 0.012 & 0.022 & 0.007 & 0.005 \\
\hline \hline
\end{tabular}

Panel C: Summary statistics of $\beta$ for Portfolio 'High'

\begin{tabular}{cccccc}
\hline \hline & $\mathbf{r}_{\text {gls }}$ & $\mathbf{r}_{\mathbf{c t}}$ & $\mathbf{r}_{\text {gordon }}$ & $\mathbf{r}_{\mathbf{o j n}}$ & $\mathbf{r}_{\mathbf{f f}}$ \\
\hline Time-series mean & 0.583 & 0.077 & 0.228 & -0.225 & 0.057 \\
Std Error & 0.689 & 0.572 & 0.575 & 0.377 & 0.106 \\
t-stat & 0.846 & 0.134 & 0.397 & -0.598 & 0.541 \\
Time-series median & -0.271 & -0.114 & 0.178 & 0.205 & -0.064 \\
Mean adj. $\mathrm{R}^{2}$ in \% & 0.020 & 0.029 & 0.036 & 0.030 & 0.006 \\
\hline \hline
\end{tabular}


Table 8: Multiple regressions including lagged annual return to control for bias due to analyst forecast sluggishness

This table provides the time-series statistics of the slope coefficients $(\beta$ and $\gamma)$ from the following regression: $R_{1}=\alpha+\beta r_{i}+\gamma R_{0}+\varepsilon$. The cost of capital measures, $r_{\text {gls, }}$ $r_{c t}, r_{\text {gordon, }} r_{\text {ojn, }}$ and $r_{f f}$ are defined in Table 1 and are estimated as of June $30^{\text {th }}$ each year. $R_{0}$ is the stock return measured from July to June during the one-year period over which the change in cost of capital variable is computed. We run the cross-sectional regression for each year, and present the time-series descriptive statistics of the slope coefficients. We perform the regressions both at a firm level (Panel A) and at an industry level (Panel B). The industry portfolios are formed based on the

Fama and French classification of 48 industries.

Panel A: Summary statistics of firm-level regression coefficients

\begin{tabular}{|c|c|c|c|c|c|c|c|c|c|c|}
\hline & \multicolumn{2}{|c|}{ (1) } & \multicolumn{2}{|c|}{ (2) } & \multicolumn{2}{|c|}{ (3) } & \multicolumn{2}{|c|}{ (4) } & \multicolumn{2}{|c|}{ (5) } \\
\hline & $\mathbf{r}_{\mathrm{gls}}$ & $\mathbf{R}_{\mathbf{0}}$ & $\mathbf{r}_{\mathrm{ct}}$ & $\mathbf{R}_{\mathbf{0}}$ & $\mathbf{r}_{\text {gordon }}$ & $\mathbf{R}_{\mathbf{0}}$ & $\mathbf{r}_{\mathbf{o j n}}$ & $\mathbf{R}_{\mathbf{0}}$ & $\mathbf{r}_{\mathrm{ff}}$ & $\mathbf{R}_{\mathbf{0}}$ \\
\hline Time-series mean & 0.50 & 0.08 & -0.00 & 0.07 & 0.29 & 0.08 & -0.25 & 0.07 & 0.09 & 0.07 \\
\hline t-stat & 1.40 & 2.70 & -0.01 & 2.27 & 1.36 & 2.39 & -1.20 & 1.96 & 1.11 & 2.25 \\
\hline Time-series median & 0.55 & 0.08 & 0.14 & 0.08 & 0.30 & 0.08 & -0.26 & 0.05 & 0.03 & 0.06 \\
\hline
\end{tabular}

Panel B: Summary statistics of industry-level regression coefficients

\begin{tabular}{|c|c|c|c|c|c|c|c|c|c|c|}
\hline & \multicolumn{2}{|c|}{ (1) } & \multicolumn{2}{|c|}{$\overline{~(2) ~}$} & \multicolumn{2}{|c|}{ (3) } & \multicolumn{2}{|c|}{ (4) } & \multicolumn{2}{|c|}{$\overline{~(5)}$} \\
\hline & $\mathbf{r}_{\mathrm{gls}}$ & $\mathbf{R}_{\mathbf{0}}$ & $\mathbf{r}_{\mathrm{ct}}$ & $\mathbf{R}_{\mathbf{0}}$ & $\mathbf{r}_{\text {gordon }}$ & $\mathbf{R}_{\mathbf{0}}$ & $\mathbf{r}_{\mathbf{0 j n}}$ & $\mathbf{R}_{\mathbf{0}}$ & $\mathbf{r}_{\mathrm{ff}}$ & $\mathbf{R}_{\mathbf{0}}$ \\
\hline Time-series mean & 1.22 & 0.17 & 0.46 & 0.17 & 1.05 & 0.17 & -0.45 & 0.13 & 0.05 & 0.16 \\
\hline t-stat & 2.73 & 2.25 & 0.64 & 2.04 & 2.05 & 2.11 & -0.95 & 1.54 & 0.18 & 1.79 \\
\hline Time-series median & 1.14 & 0.17 & 0.67 & 0.17 & 1.15 & 0.16 & -0.68 & 0.15 & -0.09 & 0.17 \\
\hline
\end{tabular}


Table 9: Regressions of future annual returns on adjusted cost-of-capital measures that correct for analyst forecast sluggishness

This table is identical to Table 3 except that: i) in Panels A and B, the four accounting-based cost of capital models defined in Table 1 are estimated using stock price, $\mathrm{P}_{0}$, as of January instead of June (i.e., five-months earlier than in Table 3), and ii) in Panel B, for each firm, in each year, we also exclude individual analysts' forecasts if they are in the oldest one-third of the forecasts made for that firm. As above, we continue to estimate the cost of capital measures, $r_{\mathrm{gls}}, \mathrm{r}_{\mathrm{ct}}$, $r_{\text {gordon, }} r_{\text {ojn }}$ and $r_{\mathrm{ff}}$ as of June $30^{\text {th }}$ each year using analysts' forecasts as of June. Using stock price in January and analysts' forecasts in June allows analysts approximately five months to incorporate information contained in recent stock returns prior to January. The table below provides the time-series statistics of the slope coefficients of the following regression: $R_{1}=\alpha_{1}+\beta_{1} r_{i}+\varepsilon_{1}$. The dependent variable, $R_{1}$, is one-year-ahead stock returns starting from July $1^{\text {st }}$ after the June $30^{\text {th }}$ measurement date for the cost of capital measures. We run the cross-sectional regression for each year, and present the time-series descriptive statistics of the slope coefficients. We perform regressions both at firm level and industry level. The industry portfolios are formed based on the Fama and French classification of 48 industries.

Panel A: Summary statistics of $\beta_{1}$ from: $R_{1}=\alpha_{1}+\beta_{1} r_{i}+\varepsilon$, where $r_{i}$ is estimated using stock price from January in the valuation model (i.e., stock price is five months earlier than in Table 3 ).

\begin{tabular}{|c|c|c|c|c|c|c|c|c|}
\hline & \multicolumn{4}{|c|}{ Firm level } & \multicolumn{4}{|c|}{ Industry level } \\
\hline & $\mathbf{r}_{\text {gls }}$ & $\mathbf{r}_{\mathrm{ct}}$ & $\mathbf{r}_{\text {gordon }}$ & $r_{\text {ojn }}$ & $\mathbf{r}_{\mathrm{gls}}$ & $\mathbf{r}_{\mathrm{ct}}$ & $\mathbf{r}_{\text {gordon }}$ & $\mathbf{r}_{\mathbf{0 j n}}$ \\
\hline Time-series mean & 0.87 & 0.46 & 0.71 & 0.04 & 0.53 & -0.83 & 0.25 & -0.68 \\
\hline Std Error & 0.49 & 0.36 & 0.42 & 0.33 & 0.86 & 0.88 & 0.82 & 0.59 \\
\hline t-stat & 1.78 & 1.29 & 1.70 & 0.12 & 0.62 & -0.95 & 0.30 & -1.16 \\
\hline Time-series median & 0.65 & 0.35 & 0.89 & -0.27 & 1.32 & -0.53 & 0.11 & -0.59 \\
\hline Mean adj. $R^{2}$ in $\%$ & 1.8 & 1.0 & 1.9 & 1.1 & 4.7 & 4.2 & 6.2 & 2.8 \\
\hline
\end{tabular}

Panel B: Summary statistics of $\beta_{1}$ from: $R_{1}=\alpha_{1}+\beta_{1} r_{i}+\varepsilon$, where $r_{i}$ is estimated excluding stale analysts' forecasts and using stock price from January in the valuation model (i.e., stock price is five months earlier than in Table 3).

\begin{tabular}{|c|c|c|c|c|c|c|c|c|}
\hline & \multicolumn{4}{|c|}{ Firm level } & \multicolumn{4}{|c|}{ Industry level } \\
\hline & $\mathbf{r}_{\mathrm{gls}}$ & $\mathbf{r}_{\mathrm{ct}}$ & $\mathbf{r}_{\text {gordon }}$ & $\mathbf{r}_{\mathbf{o j n}}$ & $\mathbf{r}_{\mathrm{gls}}$ & $\mathbf{r}_{\mathrm{ct}}$ & $\mathbf{r}_{\text {gordon }}$ & $\mathbf{r}_{\mathbf{0 j n}}$ \\
\hline Time-series mean & 0.97 & 0.37 & 0.63 & 0.00 & 1.77 & 0.04 & 0.90 & -0.26 \\
\hline Std Error & 0.59 & 0.47 & 0.53 & 0.30 & 0.80 & 0.91 & 0.82 & 0.60 \\
\hline t-stat & 1.64 & 0.78 & 1.20 & 0.01 & 2.21 & 0.04 & 1.10 & -0.43 \\
\hline Time-series median & 0.81 & 0.35 & 0.94 & -0.09 & 2.28 & 0.87 & 1.21 & -0.17 \\
\hline Mean adj. $\mathrm{R}^{2}$ in $\%$ & 2.5 & 1.4 & 2.5 & 0.1 & 6.7 & 5.4 & 7.2 & 2.3 \\
\hline
\end{tabular}

